\title{
ENLIGHTENED MODERATION UNDER PERVEZ MUSHARRAF REGIME
}

\author{
Syeda Afshan Aziz ${ }^{*}$ \\ Tanweer Khalid $^{* *}$
}

\begin{abstract}
Pervez Musharraf was the thirteenth Chief of the Army staff (COAS) and tenth president of Pakistan. In October 1999, he took over as a Chief Executive of Pakistan by dismissing then Prime Minister Nawaz Sharif. Military takeover was savored by the people of Pakistan due to bad governance of democratic Governments. Unlike the former dictator Gen Zia ul Haq, Gen. Pervez. Musharraf gave the impression of being secular and liberal. He was an ardent admirer of Mustafa Kamal Ataturk and wanted to establish Turkish Model of democracy in Pakistan. To delink Islam from extremism and fundamentalism, he introduced the strategy of "enlightened moderation" which has been discussed in this paper. Many Pakistanis welcomed his policy of "enlightened moderation" and even OIC acknowledged his approach. He worked sincerely to uplift the status of women in the society. He also led the army in the war against terrorism and launched operation against militants who were challenging the writ of the Government. The economy of Pakistan was at its peak and poverty graph was declining in Pakistan during his period when many sociological changes in the country took place.
\end{abstract}

Keywords: Enlightened moderation, liberal ruler, extremism, fundamentalism

\section{Introduction}

There has been great influence of military in the political process of Pakistan. The main reason behind is that from 32 years, there were four time coup by the military generals and ruled the country without any serious protest by public. Due to this, military has been playing a key role in designing and formulating the policies for internal and foreign affairs of the state.

The tradition of military's involvement in government's matters was set out when in 1954 Ayub Khan, a serving COAS, was given the portfolio of Defense in the Federal cabinet of Muhammad Ali Bogra and in October, 1958 the then President Iskinder Mirza enforced General Ayub to take over as Martial Law administrator after which General Ayub also took the charge of presidential office from Iskinder Mirza. The people welcomed the takeover as they had become frustrated from politicians. Ayub was a liberal and moderate general and believed in innovative vision of Islam. His liberalism and moderation towards Islam was clearly evident in his policies in his first

\footnotetext{
"Syeda Afshan Aziz, Ph.D. student, Department of Political Science University of Karachi

${ }^{* *}$ Tanweer Khalid, Ph.D. Professor of Political Science, University of Karachi. Head of the Department of International Relations, Preston University, Karachi
} 
half. Ayub's era is acknowledged for the industrialization.He encouraged the private sector to establish small-scale industries and thus opened up opportunities for jobs. During 1960-65 the investment graph touched the peak of 21.5 per cent of GDP and Pakistan registered first ever surplus budget. He introduced educational reforms and also tried to work for land reforms but this initiative could not be succeeded. $\mathrm{He}$ designed a new city, Islamabad, and shifted the capital here from Karachi. General Ayub's era was very satisfactory in terms of economy, industrialization and agricultural development but he had to resign in very humiliation way.

The Martial Law which had the strongest impact was Genera Zia's coup. He governed the country solitarily for the longest period. ${ }^{1}$ On April,1976, Zulfiqar Ali Bhutto, the then Prime Minister, appointed Zia ulHaq as COAS superseding five senior Generals but only after one year and three months he took over the government through a bloodless coup and started to abridge political activities and fundamental rights on a day-by-day basis. He also enforced accountability of politicians and many of them were disqualified through the disqualification tribunal. He introduced the Majlis-eShoora and established military courts along with the Federal Shariat Court parallel to High Court. After eight years of absolute dictatorship, and crack down of political parties in 1985, he halfheartedly and presumably rendered partial command to a timorous government which was formed through a non-party base election. General Zia managed to obtain support from conservative and orthodox Islamic groups forming policies in their interest. He also succeeded to attain favor from the United States for resisting Soviet Union in Afghanistan. ${ }^{2}$ During Zia's era, role of military became more evident in the economic sector. Religious extremism and militancy are major fallout of his era.

The military once again took the control of government when on 12 October, 1999 General Musharraf dismissed Prime Minister Nawaz Sharif through a bloodless coup. ${ }^{3}$ His era caused many changes in society. After the incident of $9 / 11$, he chose to be the ally of the United States. On April 30, 2002; he extended his period as president for next five years through a referendum and on 24 August, 2002, He issued Legal Framework Order (LFO) through which some constitutional changes were made. Operation of Lal Masjid, assassination of Bughti and sacking of Chief Justice are his some controversial acts.

\section{Musharraf and "Enlightened Moderation"}

General Musharraf spent his middle childhood and adolescence in Turkey. ${ }^{4}$ This is the age group where a person's psychological and social characteristics change and build up. At that time the successor of Ataturk, Ismet Inonu of Republican People's Party was the president and Turkey, with the reforms of Ataturk, had established itself as a

${ }^{1}$ Siddique, O. The Jurisprudence of dissolutions: presidential power to dissolve assemblies under the Pakistani Constitution and its discontents.Arizona Journal of International and Comparative Law,23(3), (2006).

${ }^{2}$ Hilali, A. Z. The costs and benefits of the Afghan War for Pakistan.Contemporary South Asia, 11(3), (2002).291-310.

3Shah, A. Democracy on hold in Pakistan. Journal of Democracy,13(1), (2002), 67-75.

${ }^{4}$ Musharraf, P. In the line of fire: A memoir. Simon and Schuster, (2006) 
secular country. Kamalism was in full possession; therefore, it was a quite natural for a young child to take effect. That is why General Musharraf was a great admirer of Mustafa Kamal Ataturk. During his tour to Turkey as a Chief Executive of Pakistan in November, 1999 and visited the tomb of Ataturk where articulating his admiration, he compared himself with General Kenan Evren, who displaced $\mathrm{Mr}$ Ecevit and Mr.Demirel in a takeover in 1980. ${ }^{5}$ Pervez Musharraf's fondness for Turkey played a pivotal role in formation of "enlightened moderation" policy. No one can doubt his efforts which he made for this regard in Pakistan as well as in the Islamic world. ${ }^{6}$

The incident of 9/11 had a profound effect on the whole Muslim world. After the attack, without any delay Western Media turn on Muslim world and started to consider Muslims as terrorist, fundamentalist, extremist, and fanatics. ${ }^{7}$ Being the first neighbor of Afghanistan, where terrorism was breeding; its impact on Pakistan was a certain reality. Gen Musharraf was the ruler of Pakistan and he has to decide whether Pakistan was to go with her neighbor or with the international community and the United States. Pakistan was already facing restrictions after its nuclear explosions and that decisive moment required great wisdom, cognition and ability. Gen Musharraf chose to be the ally of U.S. and countered the charges of extremism and fanaticism with the policy of "enlightened moderation". Musharraf recommended Muslims that they should follow the path of moderation to prove that Islam is a religion of humanity, harmony and peace instead of terrorism, extremism and fanaticism. He emphasized that Muslims have to prove that there is no connection between militancy and Islam through their words and deeds. Many Pakistanis appreciated the approach.

"Enlightenment" and "Moderation" are not only two attractive terms. If we look upon Muslim pedagogy, we acknowledge that "enlightened moderation" is the true essence of Islam. Islam encourages moderation in all fields of life; concerning one's individual matters to community life, in peace and war. "Enlightened moderation" is not only a theory but it is a complete strategy which demands planning and practical arrangement especially when it is related to a nation. ${ }^{8}$ So for the practical implementation of this policy Gen Pervez Musharraf also took some steps, although he didn't succeed completely but some of his standards changed the way of thinking of Pakistani nation in national policies as his slogan "Sab Se Pehlay Pakistan" gained recognition countrywide. His efforts in the following fields are praiseworthy:

- Development of Education/ Science and Technology

- Empowerment of Women

- $\quad$ Freedom of Print and Electronic Media

- Economic Growth

- Operation against Terrorism

\footnotetext{
${ }^{5}$ Bishku, M. B. Turkey and Iran during the cold war.Journal of Third World Studies, 16(1), (1999),13

${ }^{6}$ Gazdar, H. Musharraf's Legacy. Economic and Political Weekly, 42(14), (2007),1236

${ }^{7}$ Fawn, R. Global responses to terrorism: 9/11, Afghanistan, and beyond. (Psychology Press. 2003)

${ }^{8}$ Musharraf, P. A plea for enlightened moderation.Washington Post, 1, A23, (2004)
} 


\section{Development of Education/ Science and Technology}

Enlightened moderation is very closely related with the development and spread of education. Gen Pervez Musharraf believed that education was the key element of social and economic development and their countries which have exposed the secret of development in the education of children are investing widely for the technical education and engineering. Education is the key to development where awareness is inculcated and a balanced sense of approaches are made possible.

The efforts which were made for the betterment of education during Musharaf's era, all democratic parties could not do in 66 years. He introduced many reforms in the education sector and appointed Dr Atta-ur-Rahman as the Federal Minister for Science and Technology in March 2000 who worked for this ministry enthusiastically made the government to agree to increase the budget $6000 \%$ from 2001 to 2003 for science and technology. This not only created job opportunity, it also uplifted the living standards of the people. Tools of new technology like the internet, mobile, computer and laptops were brought in the approach of a common man where it played a revolutionary role. Virtual university is an example of technology based education.

\section{Federal actual expenditures on education in million rupees}

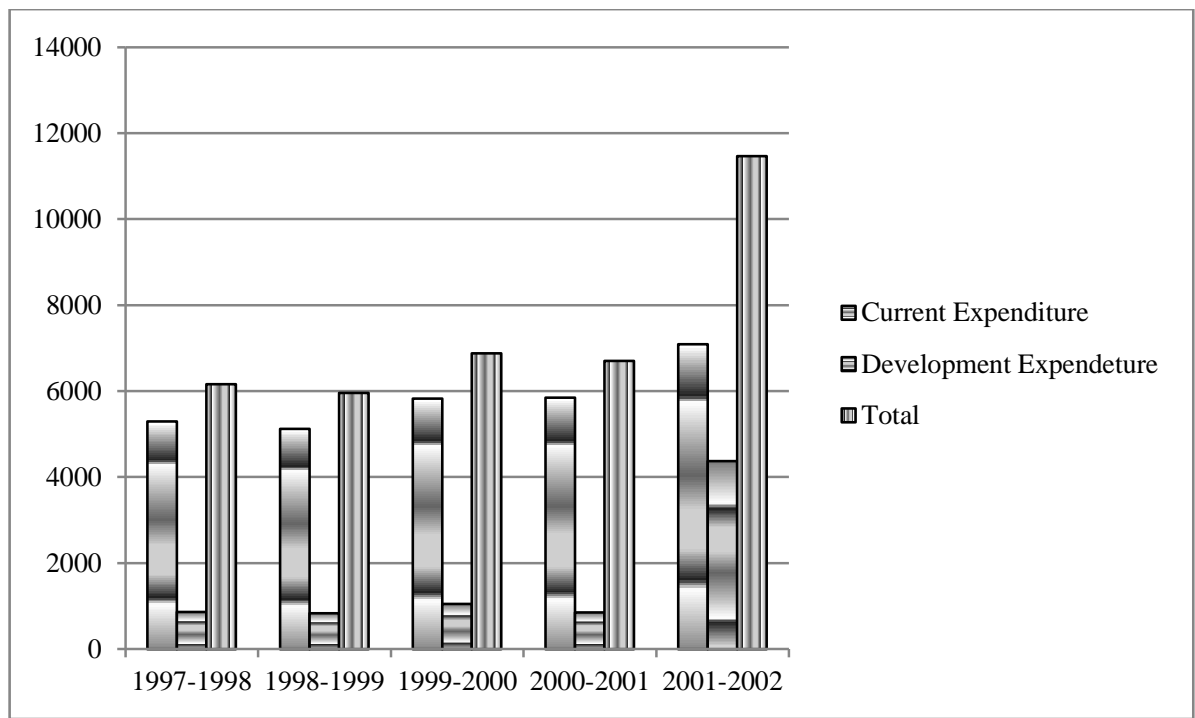

Source: Government of Pakistan, Finance Accounts (1997-98-2001-02) and Civil Accounts (200102), Auditor General of Pakistan, Islamabad.

On the bases of projects which were done between the period of 1999 to 2007, Pakistan got reorganization for higher education and because of these projects which lead towards knowledge-based economy. Gen Musharraf established the Higher education commission (HEC) in 2002. Believing in "Right man for the right job", General Musharraf once again appointed Dr Atta-ur-Rahman as the Chairman of Higher 
Education Commission (2003-2008) who set up an educational revolution in the whole country. ${ }^{9}$ Universities were coerced and helped out by the Government to implement international education standards. The target assigned to Dr. Atta-ur-Rahman was to improve the quality of education in Pakistan's public sector universities. It was the very first time that Research Grants were given for universities and digital libraries were established. More than five thousand people were sent for $\mathrm{PhD}$ studies at foreign universities and scholar's citation improved by 100\% during his tenure. Five major research institutions were established in Pakistan in which Abdul-Salam School of mathematical sciences (GC University), School of Biological Sciences (Punjab University), and School of Physical Sciences tops the list. Today, world standard research is being carried out in these institutions and experts from different countries are working here.

To build Pakistan's economy into "Knowledge-based Economy", many projects were launched. Classification mechanism was introduced to promote competition between universities. Teacher's promotion was linked to the publication of research papers and salaries were also increased up to $100 \%$ so that the culture of research could be raised. Because of these projects, the degree value of Pakistani institution were being acknowledged in the world and on the bases of Knowledge Economy, advancement of Science and Technology was pursued in Pakistan.

The educational development during Musharraf's era even upset the Indian authorities. They re-examined the Pakistan's educational plan to compile a report ('Pak threat to Indian Science') and asked the Government to adopt the same system. Nine engineering universities were established on international standards and eighteen more universities were established. The literacy rate which was only 42.7 in 1999 rose up to 54.15 in 2007. ${ }^{10}$ Musharraf also tried to make reforms in Madrassa curriculum but he could not achieve any significant success in this context.

\section{Empowerment of Women}

Women make almost $51 \%$ of Pakistan's population. Countries cannot make progress without the development of women. When General Pervez Musharraf took over the charge of country in 1999, the circumstances for women were not so good. It was not that his predecessors totally ignored women's rights, Benazir being a woman had been a prime minister of this country but still a great deal in legislation was required. Luckily, General Musharraf was liberal enough for women's rights. He, by appointing female activist in his cabinet, drew the future line of his policy. ${ }^{11}$

Different organizations were struggling to facilitate women in politics and for their representation in parliament but it did not seem more than a fantasy. Even during Benazir Bhutto's regime, who was also known as a liberal politician, representation of

\footnotetext{
${ }^{9}$ Rashid, S. Trends in Access and Quality of Higher Education in Pakistan: A Research based on three Case Studies, (2011)

${ }^{10}$ Memon, G. R. Education in Pakistan: The key issues, problems and the new challenges. Journal of Management and Social Sciences, 3(1), (2007), 47-55.

${ }^{11}$ Zia, A. S. The reinvention of feminism in Pakistan.Feminist review, 91(1), (2009), $29-46$.
} 
women in the parliament was only $1.4 \%$. Her party also tried to increase the women quota in parliament by beseeching political support from the opposition. However, legislation about women's right was reexamined during Musharraf era and women got record rights in every walk of life. They were given representation in Parliament, were appointed in the armed forces and federal cabinet and got share in public services. They were also supported for cultural and art expression and activities. ${ }^{12}$

On the occasion of International Women's Day, on 08 March, 2002 Gen Musharraf vowed to establish an independent National Commission for Women and said that Pakistan would increase the number of reserved seats in both national and Provincial assemblies. He also gave a package of three-month pardon for women detainees which facilitated the large number of women prisoners imprisoned for zina charges. He also made necessary amendments in the constitution through the Legal Framework Order (FLO 2002) to increase the quota of overall reserved seats of women in Parliament. First time 60 seats were reserved for women. In 2002 election, it was for the very first time that such a big number of women became part of the parliament. Twelve women were also elected directly and reserved seats were divided among parliamentary parties according to their representation. The MMA, about which some circles had opinion as fundamentalist group, also filled 12 reserved seats with its women. ${ }^{13}$

To rectify the image of Pakistan in the world, his government passed laws including the Criminal Law (Amendment) Act of 2004 which is known as "honor killing law," In this law punishments for honor killings were enhanced. Furthermore during Musharraf tenure, Protection of Women Act 2006 was passed through which adultery and rape crimes were place back into Pakistan's Penal Code. Although many plans of Gen Pervez Musharraf remained incomplete, however he succeeded to change the mindset of the society overall.

The position of women in Pakistan is a matter of deep concern. Yet the ethics have changed only by name where women are the part of an institution with some liberty, tough customs are pushing them down. But it is a good thing that circumstances are going toward better due to the educational uplift, awareness through media, feeble control of feudal society and need of competitive business culture; and we can predict that the future of women in Pakistan is moving towards the better. The amazing functioning of women in workplaces, the increasing rate of girls in higher education, different Government's schemes for women, reserved seats in parliament and in other Government institutions; all these are indications of bright future of women and alternately a prosperous Pakistan.

\section{Freedom of Print and Electronic Media}

In the early 1990s, broadcast media systems were completely under the control of National Government and then commercial market of media came forth. Before it people had no option and were forced to listen or see what Government wanted.

${ }^{12}$ Mahmood, S.The Musharraf regime and the governance crisis: a case study of the government of Pakistan. (Nova Publishers, 2001)

${ }^{13} \mathrm{Zia}$, A. S. The reinvention, Op.cit. 29-46. 
People had started to take on illegal satellite dishes and other means in reaction of Government repression. ${ }^{14}$ After the takeover of Gen Musharraf, in 2002 media started a new journey and it is accepted that Musharraf played a major role in the development and freedom of media. The way, through which he broke the monopoly of National Channel, it was totally his individual decision. He established Pakistan Electronic Media Regulatory Authority (PEMRA) on 01 March, 2002 whose main object was to legalize the electronic media affairs. PEMRA started to facilitate private media channels and issued licenses open heartedly and suddenly a great network of private media channels was established. Now there is a long list of private TV Channels including NEWS, Educational, Health and Islamic channels along with entertainment Channels.

Media has also played a significant role in the economy by creating jobs. Now media is an industry in which millions of people are employed and are getting livelihood. It has brought wellbeing in journalists' living and they are getting very attractive salaries from different TV channels. ${ }^{15}$ Media has multidimensional role in the world, it is not mere a source of entertainment but it is also educating people and keeping them informed. Its role has assumed great importance. It is promoting the policy of "enlightened moderation" where on matters; people can build up their own opinion after knowing different aspects. It is the obligation of media persons that they should preach tolerance and patience instead of intractability and impatience.

\section{Economic Growth}

Economy has a central role in the development and affluence of any country. Strong economy causes progress in the body of a society. Poverty and bad economy of any country is a major cause of extremism and social decline. At the time of Army coup in 1999, the economy of Pakistani was nearing to collapse. ${ }^{16}$ General Musharraf rescued the economy and his withdrawal of support for the Taliban brought out Pakistan from international isolation. America ruled out further restrictions on Pakistan and an immense U.S. aid came in the country in 2001. He brought improvement in macroeconomic performance which made possible to re-enter the international capital markets. ${ }^{17}$ During Musharraf's era from 1999 to 2007, the economy showed accelerated growth with an average rate of $7 \%$. In the second term of PML (N), dollar had reached to Rs 53 from Rs 40.6 in 1996. He restrained the dollar up to Rs62 in 9 year of his rule. A hefty capital inflow sustained the current account and at the end of June 2007 gross official reserves were \$14.3 billion and poverty's graph came downward very quickly from 2001 to 2007 . Its effects reached also in rural areas standard of life became better. ${ }^{18}$

\footnotetext{
${ }^{14}$ Iqbal, Z. Media and Musharraf: A Marriage of Convenience. European Scientific Journal, 8(3), (2012)

${ }^{15}$ Fruman, S.Will the long march to democracy in Pakistan finally succeed?.(US Institute of Peace, 2011)

${ }^{16}$ Zaidi, S. A. Musharraf and His Collaborators.Economic and Political Weekly, 42(45/46), (2007),8

${ }^{17}$ Kronstadt, K. A. Pakistan's Domestic Political Developments. (Washington DC: Library of congress Congressional Research Service, 2005)

${ }^{18}$ Haque, N. U., Burki, S. J., Hasan, P., Hasan, P., Hussain, A., \&Ikram, K. Beyond Planning and Mercantilism: An Evaluation of Pakistan's Growth Strategy [with Comments]. The Pakistan Development Review, (2006) 3 .
} 


\section{POVERTY REDUCTION UNDER PRESIDENT MUSHARRAF}

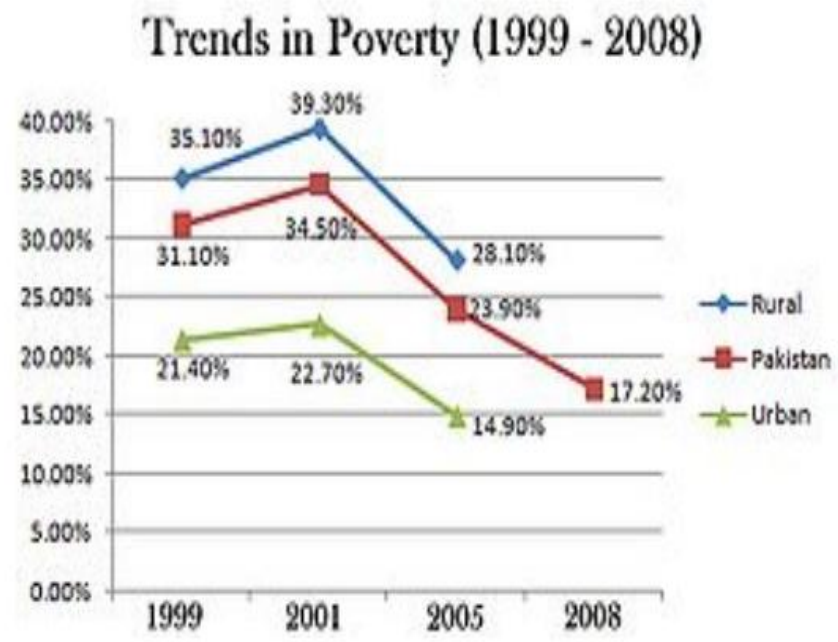

Figure 2:- Shows the poverty reduction in era (1999-2008).

The IMF has also accepted that during 2000 to 2007, Pakistan was in the top four countries which developed their economy very fast. Its average growth was $7 \%$ per year during this period. This was the reason that Pakistan succeeded to reduce poverty up to 50 per cent. Job opportunities were increased and almost 13 million people got jobs and debt burden of the country became half. Reserves of foreign exchange got a push and settled at satisfactory position. These measures restored the confidence of foreigner investors.

\section{Research Methodology}

This research paper is based on the following methodology:

Theoretical and analytical in view of the prevalent political environment. Comparative to a limited extent with the earlier elected government.

\section{Operation against Terrorism}

Terrorism is the use of violence and cruelty for political benefits. It is actually the opposite of "enlightened moderation". These are inversely proportional to each other. A country having elements of terrorism cannot be moderate and enlightened. Today this is the major issue of the whole world. After 9/11, Pakistan has been facing the curse of terrorism. Gen Musharraf was very rigid toward terrorists and despite political opposition he launched army operation against terrorists. He tried to teach the Pakistani people that Pakistan comes first and he raised the slogan "Sab se Pehlay Pakistan". He was very well aware of the drawbacks of extremisms. He adopted a 
very comprehensive strategy to counter this curse and took many administrative steps. $^{19}$

\section{Conclusion}

The civilian government has been remained the poor administrator throughout the history of Pakistan, that's why people had never expressed any disapproval whenever military carried coup. General Musharraf 's coup was also welcomed by the populace of Pakistan and he was at the helm of affairs of Pakistan for 8 Years and 10 Months. During his era, the incident of 9/11 reshaped the world's politics. Pakistan could not make any progress being in isolation so being the first line ally of the United States in war; General Musharraf got political, diplomatic and economic support from the western world particularly from the United States. His stated object was to streamline the political, electoral and economic systems. Although Military Government has many drawbacks and it is not an ideal situation for a country, but above all Musharraf's era was of great importance and he laid down many good traditions. He strengthened the economy, tried to delink religion and terrorism and raised educational revolution across the country. His policy of "enlightened moderation" influenced the enlightened circles of the society. This policy also appealed foreign investors who came and helped in economic stability and progress. Although, his political allies were involved in ransacking but no one can charge Musharraf himself for corruption and he succeeded to trim down the budget deficit. Even though he was a military ruler, he emphasized on democracy. He believed in devolution of power and he managed local body elections. During his tenure parliament completed its term and power was handed over to the next civilian government and luckily the next Government also completed its tenure and so a positive tradition was built. He focused on education and gave importance to educational institutions which brought good name for the country among the nations of the world. His efforts made Pakistan an enlightened and moderate country.

\section{Bibliography}

Hassan, Abbas Pakistan's Drift into Extremism: Allah, the Army and America's War on Terror (Armonk, NY: M.E. Sharpe, 2005).

Jones, Owen Bennett, Pakistan: Eye of the Storm (New Haven, CT: Yale Nota Bene, 2002).

Coughley, Brian, A History Of the Pakistan Army: Wars and Insurrections, Karachi: OUP, 2006.

Siddiqa, Ayesha, Military Inc. Inside Pakistan's Military Economy (London/Anne Arbor: Pluto Press, 2007).

Devji, Faisal, Landscapes of the Jihad: Militancy Morality, Modernity (New York: Cornell University Press, 2005).

Nawaz, Shuja, Crossed Swords: Pakistan, Its Army and the Wars Within (Karachi: Oxford University Press, 2008).

\footnotetext{
${ }^{19}$ Cook, d. D. B. Radical Islam and martyrdom operations: what should the United States do?, (2004)
} 
Rizvi, Hasan Askari, Military, State and Society in Pakistan (London: Palgrave Macmillan, 2003).

Talbot, Ian, Pakistan: A Modern History, $2^{\text {nd }}$ edn (London: Hurst, 2009). 